\title{
Export subsidies, countervailing duties, and welfare
}

YU-TER WANG*

Using a simple Cournot duopoly model, this paper provides an important policy implication for trade disputes involving export subsidies. In this paper, the possibility that a foreign export subsidy could benefit the domestic country as well as the foreign country by appropriately using countervailing duties is identified.

Keywords: Export subsidies; Countervailing duties; Welfare; Countervailing percentage; Cost-efficiency

JEL Classification: F12; F13; L13

\section{INTRODUCTION}

In the literature on strategic trade policy, Brander and Spencer (1985) show that a foreign export subsidy will increase foreign welfare in the absence of retaliation. $N$ ext, Dixit (1988) shows that the optimal domestic response to a foreign export subsidy is to retaliate with a partial countervailing duty (CVD) and Collie $(1991,1994)$ shows that a foreign country would be deterred from subsidizing exports when the optimal partial CVD is adopted. By contrast, Q iu (1995) offers some factors, including the delay in retaliation, the CVD level and voluntary export restraints, to explain why the CVD measures cannot deter the foreign export subsidy. In a recent study, by separating CVD determination from the import tariff, Wang (2004) finds that whether the optimal CVD can deter the export subsidy set by the foreign government depends on the existing import tariff level.

Until now, how ever, what is not considered is whether foreign export subsidies can benefit the domestic country as well when it improves foreign welfare. If the

* Department of Economics, M ing Chuan University, N 0. 5, Teh-M ing Rd., G wei-Shan, Taoyuan 333, Taiwan. E-mail: ytwang@mcu.edu.tw. Submitted: O ctober 2004; accepted: February 2005. 
answer is affirmative, then why will the domestic country bar the foreign country from subsidizing exports? The purpose of this paper is to examine this issue.

Differing from the previous model in the literature on export subsidies and CVDs, this paper assumes that trade policies are determined in an exogenous way, because of political factors and other such considerations, with the result that optimal trade policies that maximize national welfare are usually unavailable in practice. For instance, the pressure exerted by certain countries, such as Brazil and Australia, in the WTO negotiations has forced the U.S. to promise to remove some of its subsidies on agricultural exports (see also $\mathrm{H}$ ansen and Prusa (1997)). Under such a setting, this paper identifies the possibility that a foreign export subsidy can benefit the domestic country as well as the foreign country when the CVD is used appropriately.

\section{THE MODEL AND ANALYSIS}

In this simple model, only two countries are involved: the domestic and the foreign country. The domestic country's variables are denoted by the subscript $d$ and the foreign country's variables by the subscript $f$. The industry analyzed is a homogeneous product Cournot oligopoly with one firm located in each country, and the domestic and the foreign markets are assumed to be segmented. The domestic firm produces $x_{d}$ for domestic consumption at a constant average cost, $c_{d}$, and a fixed cost, $F_{d}$, and the foreign firm produces $x_{f}$, which is exported to the domestic market, at a constant average cost, $c_{f}$, and a fixed cost, $F_{f}$. Thus, total sales in the domestic market are $X=x_{d}+x_{f}$. The price, denoted by $p$, in the domestic market is given by the linear inverse demand function $p(X)=\alpha-\beta X$. To further simplify the analysis, $\beta=1$ is assumed without affecting the robustness of the results obtained. ${ }^{1}$ The foreign export subsidy is per unit, and the corresponding specific CVD is $\varphi s$ where $\varphi$ is the percentage of foreign export subsidy to be countervailed (the countervailing percentage).

In the model, trade policy is modeled as a two-stage game. In Stage 0, the domestic and foreign governments commit to the values of their respective trade policy instruments. $\mathrm{N}$ ext, Stage 1 involves a Cournot- $\mathrm{N}$ ash equilibrium in which the domestic and foreign firms simultaneously and independently choose their respective outputs to maximize profits given the export subsidy and CVD set by the two governments.

The profits of both the domestic and the foreign firm are:

$$
\pi_{i}=\left(p-c_{i}\right) x_{i}+D_{i}[s(1-\varphi)] x_{i}-F_{i}, \quad i=d, f,
$$

\footnotetext{
${ }^{1}$ The results obtained here are also robust when the model is extended to a nonlinear demand or a heterogeneous product case. The proof is available upon request.
} 
where $D_{i}=0(1)$ as $i=d(f)$. The first-order conditions for a Cournot-N ash equilibrium are:

$$
\partial \pi_{i} / \partial x_{i}=\alpha-2 x_{i}-x_{i}-c_{i}+D_{i} s(1-\varphi)=0, \quad i, j=d, f, \quad i \neq j .
$$

Solving for the first-order conditions, and letting $\lambda=\mathrm{c}_{d} / \mathrm{c}_{\mathrm{f}}$, yields the output of the domestic firm, the exports of the foreign firm, and the market price: ${ }^{2}$

$$
\begin{aligned}
& x_{d}=\left[\alpha+(1-2 \lambda) c_{f}-(1-\varphi) s\right] / 3, \\
& x_{f}=\left[\alpha+(\gamma-2) c_{f}+2(1-\varphi) s\right] / 3, \\
& p=\left[\alpha+(1+\lambda) c_{f}-(1-\varphi) s\right] / 3 .
\end{aligned}
$$

From these we can derive the equilibrium outputs and the market price as functions of the foreign export subsidys, the countervailing percentage $\varphi$ and the relative cost-efficiency of the domestic country as compared with the foreign country $\lambda$.

Domestic welfare is by definition the sum of the consumer's surplus, the profits of the domestic firm, and the CVD revenues:

$$
W_{d}=C S+\pi_{d}+\varphi s x_{f},
$$

where $C S=u(X)-p(X) X$. Totally differentiating $W_{d}$ with respect to $s$, using (3)-(5) and letting $s=0$ yields:

$$
\partial W_{d} /\left.\partial s\right|_{s=0}=\left[\left(\alpha-c_{f}\right) / 3\right]\left(\varphi-\varphi_{d}\right)>(<) 0 \Leftrightarrow \varphi>(<) \varphi_{d},
$$

where $\varphi_{d}=(1-\lambda) c_{f} /\left(\alpha-C_{f}\right)$. From (7), it is clear that a foreign export subsidy will increase (reduce) the domestic welfare when the countervailing percentage and hence the CVD is high (low) enough. The reason for this is as follows. Foreign export subsidies benefit consumers and harm the domestic firm while countervailing duties benefit the domestic firm and the government and harm consumers. Therefore, when the CVD is high (low) enough, the benefit from a foreign export subsidy will be greater (smaller) than the loss to the domestic country and domestic welfare will increase (decrease).

In particular, in the linear demand case, when the foreign firm is more costefficient (i.e. $\lambda>1$ ) than the domestic country so that consumers benefit more, the domestic country will benefit from foreign export subsidies even if no CVD is imposed (i.e. $\varphi=0$ ). H ow ever, when the foreign firm is less cost-efficient, a CVD will be needed if the domestic country is to benefit from the foreign export subsidies.

\footnotetext{
${ }^{2}$ For $x_{i}>0(i=d, f)$ and $\lambda>0$ the following conditions are required: $\alpha>c_{d}, c_{f}<\alpha \leq 2 c_{f}$ and $\left(2 c_{f}-\alpha\right) / c_{f}<\lambda<\left(\alpha+c_{f}\right) / 2 c_{f}$.
} 
Foreign welfare is defined as the exporting firm's profits minus the subsidy expenditure:

$$
W_{f}=\pi_{f}-s x_{f} .
$$

Totally differentiating $W_{f}$ with respect to $s$, using (3) - (5) and letting $s=0$ yields:

$$
\partial W_{f} /\left.\partial s\right|_{s=0}=\left(-4 x_{f} / 3\right)[\varphi-(1 / 4)]>(<) 0 \Leftrightarrow \varphi<(>) 1 / 4 .
$$

From (9), it can be seen that, if the countervailing percentage and hence the CVD used is low enough, a foreign export subsidy will increase foreign welfare. This is because the profits of the foreign firm increase by more than the sum of the export subsidy and the decrease in the foreign firms profits resulting from the imposition of the CVD. Therefore, if the CVD is absent, the foreign country will certainly benefit from export subsidization (see Brander and Spencer (1985)). However, if the CVD is sufficiently high, the loss from the export subsidy will dominate the benefit and thus the foreign welfare will be reduced.

The above analysis tells us that, for the domestic and the foreign country to benefit from a foreign export subsidy, the lowest level of CVD at which the domestic country can benefit from a foreign export subsidy must be lower than the highest level of CVD at which a foreign export subsidy can benefit the foreign country. $O n$ the contrary, if $\varphi_{d}>1 / 4$ the foreign welfare will be reduced because of its own export subsidy policy.

By combining ( 7 ) and (9), we see that when $\lambda>1$, i.e. the cost-efficiency of the foreign country is higher than that of the domestic country, a foreign export subsidy will al ways benefit the domestic and the foreign country even if the CVD is not used.

\section{CONCLUSION}

By using a simple model setting, this paper provides an important policy implication for trade disputes involving export subsidies. G enerally speaking, imposing a sufficiently high CVD will make the foreign country lose as a result of adopting an export subsidy policy, while a sufficiently low CVD may result in a lower level of welfare for the domestic country due to the export subsidies of the foreign government. Accordingly, to find and adopt an appropriate CVD will be necessary for both the domestic and the foreign country to benefit from a foreign export subsidy. In this paper, the possibility that a foreign export subsidy can benefit the foreign country and the domestic country by appropriately using a CVD is identified. 


\section{REFERENCES}

BRAN DER, J. A.; SPEN CER, B. J., 1985. Export subsidies and international market share rivalry. J ournal of International Economics 18: 83-100.

COLLIE, D. R., 1991. Export subsidies and countervailing tariffs. Journal of I nternational Economics 31: 309-324.

1994. Strategic trade policy and retaliation. Japan and the World Economy 6: 75-88.

DIXIT, A. K., 1988. Anti-dumping and countervailing duties under oligopoly. European Economic Review 32: 55-68

HAN SEN , W. L.; PRUSA, T. J., 1997. The economics and politics of trade policy: An empirical analysis of ITC decision making. Review of International Economics 5: 249-272.

QIU, L. D., 1995. Why can't countervailing duties deter export subsidization? J ournal of International Economics 39: 249-272.

WAN G, Y. T., 2004. Countervailing duties, foreign export subsidies and import tariffs. Japanese Economic Review 55: 153-171. 